\title{
The effect of gender, age, bodyweight, height and body mass index on plantar soft tissue stiffness
}

\author{
Jee Chin Teoh, Taeyong Lee* \\ From 4th Congress of the International Foot and Ankle Biomechanics (i-FAB) Community \\ Busan, Korea. 8-11 April 2014
}

\section{Introduction}

Foot abnormality has become a public health concern. Early detection of pathological soft tissue is hence an important preventive measure, especially to the elderly who generally have a higher risk of foot pathology (i.e. ulceration). However, the management of plantar tissue stiffness data is questionable.

The objective of this study is to assess the influence of gender and physical attributes such as height, weight and BMI on plantar soft tissue stiffness. It is also to evaluate whether it is necessary to isolate the differences in gender, age, bodyweight, height and body mass index in the data analysis procedure.

\section{Methods}

100 healthy subjects were recruited from National Seoul University (SNU) hospital for the experiment. During stiffness measurement [1], indentor tip probes the plantar soft tissue to obtain localized force response underneath the 2 nd metatarsal head pad at 3 different dorsiflexion angles of $0^{\circ}, 20^{\circ}, 40^{\circ}$ and the hallux and heel at $0^{\circ}$ Maximum tissue deformation is fixed at $5.6 \mathrm{~mm}$ (close to literature data) [2].

Tissue behavior was characterized via $\mathrm{K}$, stiffness constant.

$$
K(N / \mathrm{mm})=\frac{\text { Indentation force }(\mathrm{N})}{\text { Indentation depth }(\mathrm{mm})}
$$

T-tests were used to identify significant stiffness differences between left and right foot, as well as between male and female subjects on hallux and heel pad. Two-way

\footnotetext{
* Correspondence: bielt@nus.edu.sg Singapore

Department of Biomedical Engineering, National University of Singapore,
ANOVA was used to analyze the data obtained from subMTH pad as the stiffness of the forefoot region. The level of significance was set at $\mathrm{p}<0.05$. Pearson correlation was used to assess the relationship between bodyweight and BMI with plantar soft tissue stiffness.

\section{Results}

The male and female participants were significantly varied in weight, height and BMI, but similar in age. There was a weak correlation for both the BW and BMI with plantar tissue stiffness (Table 1a and 1b). This showed that BW and BMI are unlikely the cause for the variation in stiffness data. Gender difference also did not show influence on stiffness measurement of plantar tissue at zero MTPJ flexion (Table 2).

Table 1 Pearson correlation for (a) body weight and (b) body mass index with plantar soft tissue stiffness

\begin{tabular}{llll}
\hline (a) & & \\
\hline Plantar location & & Left & Right \\
\hline Hallux & & -0.1 & -0.06 \\
Heel & 0.12 & 0.13 \\
2nd MTH & 0.08 & 0.08 \\
& $0^{\circ}$ & 0.17 & 0.16 \\
& $20^{\circ}$ & 0.15 & 0.19 \\
\hline (b) & $30^{\circ}$ & & \\
\hline Hallux & & -0.09 & 0.02 \\
Heel & & -0.06 & -0.16 \\
2nd MTH & -0.08 & -0.08 \\
& $0^{\circ}$ & -0.13 & -0.14 \\
& $20^{\circ}$ & -0.19 & -0.12 \\
\hline
\end{tabular}


Table 2 T-test results of plantar tissue stiffness due to gender difference

\begin{tabular}{lll}
\hline Plantar tissue stiffness & $\mathrm{p}$ \\
\hline Left & & \\
Hallux & & 0.72570177 \\
Heel & & 0.21899688 \\
2nd MTH & $0^{\circ}$ & 0.48993505 \\
& $20^{\circ}$ & 0.05168678 \\
& $40^{\circ}$ & 0.01657689 \\
Right & & \\
Hallux & & 0.74204251 \\
Heel & & 0.08408934 \\
2nd MTH & $0^{\circ}$ & 0.52305598 \\
& $20^{\circ}$ & 0.05769349 \\
& $40^{\circ}$ & 0.02280329 \\
\hline
\end{tabular}

\section{Discussion}

From the experimental results, it can be deduced that BW and BMI are weakly associated with plantar tissue stiffness and there was no significant difference in stiffness between male and female participants. No difference is found between left and right feet measurement. This suggests that normalizing of plantar tissue stiffness by either variable is not necessary. The data can be pooled and treated equally regardless of gender.

Published: 8 April 2014

\section{References}

1. Chen W, et al: An instrumented tissue tester for measuring soft tissue property under the metatarsal heads in relation to metatarsophalangeal joint angle. Journal of Biomechanics 2011, 44:1804-1804.

2. Cavanagh PR: Plantar soft tissue thickness during ground contact in walking. Journal of Biomechanics 1999, 32(6):623-628.

- Convenient online submission

- Thorough peer review

- No space constraints or color figure charges

- Immediate publication on acceptance

- Inclusion in PubMed, CAS, Scopus and Google Scholar

- Research which is freely available for redistribution 